\title{
ARUDINO ÉS RAPSBERRYI PI ALAPÚ HIBRID RFID BELÉPTETŐ RENDSZER MOBIL PLATFORMMAL
}

\section{ARDUINO AND RAPSBERRY PI BASED HYBRID RFID ACCESS CONTROL SYSTEM WITH MOBILE PLATFORM}

\author{
Uszkai Sándor $^{1}$, Papp Beatrix ${ }^{2}$, Nemes Ádám ${ }^{3}$, Erdei Timotei István ${ }^{4}$ \\ ${ }^{1}$ Debreceni Egyetem, Informatikai Kar, Debrecen, Magyarország \\ uszkaisanyi@gmail.com \\ ${ }^{2}$ School of Law and Social Sciences Criminology with Psychology United Kingdom, \\ London pappb@lsbu.ac.uk \\ ${ }^{3,4}$ Debreceni Egyetem, Müszaki Kar, Mechatronikai Tanszék, 4028 Magyarország, \\ Debrecen, Ótemetö utca 2-4., (52) 415 155, ${ }^{3}$ nemes.adam96@gmail.com \\ ${ }^{4}$ timoteierdei@gmail.com
}

\begin{abstract}
Nowadays the ongoing trend of integrating everything into the cloud, connecting all sorts of gadgetry to the Internet (IoT) is basically omnipresent at this point, even in the industry, where the small and medium sized companies alike can join to this tendency. This is undoubtedly the result of the arrival of Industry 4.0, which caused an exponential growth in this field. This proposes a new challenge for the IT field, since it needs in-depth knowledge of networking and routing, and formidable knowledge of the different devices and programming languages alike. Our project premises an RFID-based fullyfledged access control system, with the targeted market of small to large companies, but also individuals, as the result of ease of use, low price, and simplicity.
\end{abstract}

Keywords: Android, Arduino, RFID, database, IoT, Industry 4.0.

\section{Összefoglalás}

Manapság a különféle eszközök hálózatba kötése és a virtuális felhők használata rohamtempóban növekszik, már-már a nagyvállalatokon túl, a kis és középvállalkozásokat is elérte. Ez természetesen az Ipar 4.0 megjelenésének köszönhető, amely ezt a robbanásszerü ugrást okozta. Ez az IT területen dolgozóknak új kihívásokat állítanak, hiszen igen mély tudást igényelnek mind a hálózati informatika, mind a hardverismeret, de a programozás terén is. Feladatunk során egy RFID-alapú, teljes beléptető rendszer létrehozására törekedtünk, melynek a nagyvállalattól, a legkisebb cégig, de még egyéni felhasználó is a célközönsége, hiszen egyszerü, olcsó, és könnyen használhatóra terveztük.

Kulcsszavak: Android, Arduino, RFID, adatbázis, IoT, Ipar 4.0.

\section{Bevezető}

Az ember internettől való félelme mára már technofóbiának fogható fel, hiszen a fejlett, és fejlődő országokban már kisgyermekkorban megismerkedünk az informatika nyújtotta vívmányokkal. Az angol Internet of Thing (IoT) avagy a „dolgok” Internete gyakorlatilag bármilyen eszköz, mely rendelkezik csatolófelülettel, hálózatba kötését jelenti, legyen az termosztát, kenyérpiírtó, vagy hủtőszekrény. Ez az új tendencia megkönnyíti ezek kezelését, müködésük megfigyelését, viszont alaposabb kiberbiztonsági intézkedések végrehajtását követelik meg [1]. 
A munka során a már kipróbált és bevált technológiák segítségével internet hozzáféréssel rendelkező IoT szemléletü beléptető rendszert hoztunk létre a Debreceni Egyetem Villamosmérnöki és Mechatronikai Tanszéke számára. A rendszer minimális átalakítással alkalmazható vállalatok számára, illetve akár a magánszférában is.

\section{Tervezési szempontok}

A Debreceni Egyetem Müszaki Karának B épületében számos kutatólaboratórium található, amelyek nagy értékű gépekkel és robotokkal vannak felszerelve. Ebböl kifolyólag világossá válik, hogy a termekbe való belépést szigorú szabályozásnak kell alávetni. Az internet korában szinte már elképzelhetetlenné vált, hogy biztonsági megoldásként a hagyományos kulcsos megoldást alkalmazzuk, ezért esett a választás az RFID technológiára. Mivel a rendszer többféle hardver- és szoftverelemet tartalmaz, a tervezés legfontosabb kérdése az volt, hogy lehet-e ezeket az eszközöket és programozási nyelveket együttesen alkalmazni, valamint az, hogy ez hogyan kerüljön megvalósításra. A kompatibilitási kérdések leküzdése érdekében a fizikai eszközök kiválasztásánál azok kerültek előtérbe, amelyek paraméterei publikusak.

A projekt szoftver komponenseinél elsősorban a platformfüggetlen programozási nyelvek élveztek előnyt.

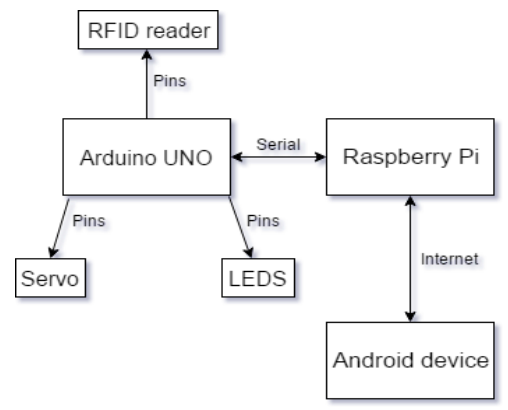

1. ábra. A rendszer elemei és azok kapcsolódási interfészei
A rendszer biztonságos müködése érdekében a belépések naplózására szolgáló adatbázis Linux alapú operációs rendszeren müködik, mivel ezek a rendszerek fokozott biztonsági komponensekkel vannak ellátva, valamint sokkal ritkábbak a sikeres támadások ellenük.

A mobilalkalmazás fejlesztése során az Androidra esett a választás, mivel ez a legelterjedtebb operációs rendszer napjainkban, ezt a piaci részesedések is mutatják.

\section{A rendszer fizikai felépítése}

A beléptető rendszer fizikai eszközeinek fontos eleme a szervomotor. Ez valósítja meg az ajtók ki-be zárását. Ehhez egy Adafruit TowerPro SG-5010 [2] típusú szervo került felhasználásra. Mivel a $39 \mathrm{~g}$ tömegü eszköz $5.5 \mathrm{~kg}$-cm forgatónyomatéka viszonylag magas, ezért alkalmas a zárak eltolására. A kiválasztásnál további szempont volt, hogy viszonylag kis feszültségről müködjön az eszköz. Mivel az optimális feszültségként a gyártó 5V-ot határozott meg, ezért kompatibilis az Arduino UNO fejlesztőpanellel.

Az UNO az Arduino gyártó egyik belépő szintű terméke, ami ideális kezdő fejlesztők számára, de bonyolultabb rendszerek vezérlésére is alkalmas. Az eszközt egy ATmega328P típusú, $16 \mathrm{MHz}$ órajelü mikrokontroller vezéreli. 14 digitális pinnel rendelkezik, ezek közül 6 képes az impulzusszélesség-modulációra (PWM). További 6 analóg pin áll rendelkezésre az analóg eszközökkel való kommunikációra, a tesztelési fázisban ezen pinek egyikébe volt bekötve a potenciométer, amivel a szervomotor szükséges forgási szöge került meghatározásra. A panel további be-és kimenetei a tápellátásért, illetve a földelésért felelősek.

Az RFID technológia előnye, hogy kényelmesen, egy érintéssel azonosíthatják magukat a belépésre jogosultak, ráadásul müködik kártyával, illetve ún. tag-ekkel is. Mivel minden kártya vagy tag egyedi azo- 
nosítóval rendelkezik, ezért a belépés csak az adatbázisban szereplö, és arra jogosult ID-vel rendelkező kártyatulajdonosok számára biztosított.

1. táblázat. Csatlakozási pontok

\begin{tabular}{|l|l|}
\hline RFID-RC522 & Arduino UNO \\
\hline SDA & Digital Pin 10 \\
\hline SCK & Digital Pin 13 \\
\hline MOSI & Digital Pin 11 \\
\hline MISO & Digital Pin 12 \\
\hline RST & Digital Pin 3 \\
\hline 3.3V & $3.3 \mathrm{~V}$ \\
\hline GND & GND \\
\hline
\end{tabular}

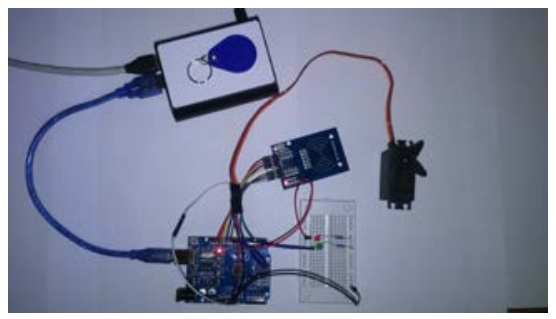

3. ábra. Az elkészült fizikai rendszer felépítése

\section{ARDUINO SKETCH}

A sketch megalkotása során elsősorban az átlátható kód létrehozása volt a kitüzött cél, valamint a gyorsaság maximalizálása. A kódolás gyorsítása érdekében előre megírt RFID.h header került a forráskódba, ami az RFID modulhoz szükséges függvényeket tartalmazza.

A kártyák azonosítója 5 számjegycsoportból áll, ezért ennek tárolására egy ötelemü tömb létrehozása szükséges.

Ahhoz, hogy azonosítani tudja az olvasó a felhasználók által használt belépőkártyákat, ellenőrizni kell, hogy a kártyaazonosító megadott tartományon belül van-e. Hamis esetben újról kezdődik a ciklus, igaz esetben az RFID eszköz leolvassa a belépőkártya azonosítóját, és kiírja azt a soros portra, ahonnan majd a Raspberry Pi-n futó Python szkript ellenőrzi, hogy szerepel-e az adatbázisban az adott számsorozat. Annak érdeké- ben, hogy a lekérdezés biztosan végrehajtódjon mire az Arduinonak szüksége lenne annak eredményére, 1 másodperces késleltetést állítottunk be.

\section{A Raspberry Pi konfigurálása}

Mivel a beléptető rendszer egyszerre egy kártyát képes kezelni, ezért az adatbázis szerveréül szolgáló fizikai egység kiválasztásánál a teljesítmény nem élvezett előnyt a költséghatékonysággal szemben. Erre a célra a projektemhez egy Raspberry Pi 2 Model B, alacsony árú, bakkártya méretü számítógépet használtam fel. Előnye, hogy többféle Linux alapú operációs rendszer futtatására alkalmas. Tárhelyként egy 8 GB méretü micro SD kártya szolgál. A rendszer gördülékenysége érdekében class 10-es gyorsaságú kártyát helyeztem el, ami az egyik leggyorsabb olvasási és írási sebességü típus.

A Linux rendszerek előnye a Windows rendszerekhez képest a nyílt forráskód, valamint a legtöbb ingyen elérhető bárki számára. Ez fontos szempont volt, mivel az iparban is a szerverek többsége Linux alapú. A Raspberry Pi eszközön egy LAMP [4] szerver került felkonfigurálásra. A LAMP mozaikszó a Linux, Apache, MySQL, PHP szavak kezdőbetüiből áll össze, ami már a nevével is elárulja a felhasznált technológiákat. Az eszközre operációs rendszerként a Raspbian legújabb verziója, a Jessie került feltelepítésre

Az Apache a legelterjedtebben használt webkiszolgáló a Linux rendszerek körében. Ez a webkiszolgáló képes a kliensek (jellemzően böngészők, de lehetnek más alkalmazások is) által kért weboldalak kiszolgálására. Támogatja a HTTP, HTTPS, valamint az FTP protokollokat.

Az adatbázis kiépítésénél fontos szerepet játszott, hogy ingyenes, nyílt forráskódú megoldás kerüljön felhasználásra, így a választás a MySQL adatbázisra esett. Elönye, hogy az adatbázis-kezelő rendkívül sokféle programozási nyelv segítségével támogatását élvezi: PHP, C++, Java, Delp- 
hi, Lisp, Perl, Python, Ruby stb. Az elkészült beléptető rendszer adatbázisának lekérdezéseinek futtatásához a PHP 5-ös verzióját választottam, mivel ez a leggyakoribb párosítás a MySQL adatbázisokhoz. A táblák vizuális tervezéséhez és létrehozásához a phpMyAdmin programot használtam fel.

\section{Android alkalmazás}

A beléptető rendszer nyomon követése kényelmetlen lenne asztali számítógépröl, SQL parancsok kézzel történő futtatásával. Innen eredt az az ötlet, hogy mobil készülékkel történhessen meg a rendszer ellenőrzése.

Az applikáció az RFIDoor nevet viseli. 2 activity-t tartalmaz: az első a MainActivity, a második a DisplayListView activity. Az Android alkalmazásoknak 4 fö komponense van: activity, service, content provider és broadcast reciever. Az activity-k hivatottak a felhasználóval való interakcióra, továbbá itt hozhatunk létre objektumokat, osztályokat definiálhatunk stb.

Az alkalmazás az angol mellett támogatja a magyar nyelvet is. A készülék lokalizációjától függően a szövegek magyar területi beállítások mellett magyarul, minden egyéb mellett angolul jelennek meg.

\section{Tesztelés és összegzés}

Abból kiindulva, hogy nincs tökéletes rendszer, a projektet számos tesztelési folyamatnak vetettük alá. Meg kellett győződnünk a felhasznált eszközök minőségéről és sértetlenségéröl, továbbá az Autodesk Circuits [7] nevű szimulációs környezetben ellenőriztük, hogy az általam kiválasztott ellenállások és LED-ek megfelelőek-e az együttes használatra. Az Android applikáció fejlesztése közben, illetve a befejezése után szintén tesztelésre került emulátoron és fizikai eszközökön egyaránt. Emulátoron a legújabb, Nougat rendszert futtató Nexus 6on végeztem tesztelést. Fizikai eszközök közül saját készülékemen, egy 5.1-es rendszerü Sony Xperia M2-n, illetve tableten is teszteltem. Mindegyik készüléken akadásmentes, és hiba nélküli volt a futás.

Az RFID technológiát használó beléptető rendszer megépítésre került, a tesztelési folyamaton sikeresen átment. A nyílt forráskódú, Linux alapú eszközök használatának, valamint a hálózati megoldásoknak köszönhetően az IoT és az Industry 4.0 föbb alapelveinek eleget tesz [8]. A rendszer szükségtelenné válása esetén annak elemei újra programozhatók, illetve újrahasznosíthatóak, így költséghatékony megoldásnak bizonyult. Előnye a gyártók által létrehozott hasonló célt szolgáló architektúrákkal szemben az, hogy teljes körü irányítást birtokolhatunk a rendszer tervezöjeként, valamint a változtatásokat is könnyebb rajta végrehajtani, mint társainál.

\section{Köszönetnyilvánítás}

A publikáció elkészítését az EFOP-3.6.1-162016-00022 számú projekt támogatta. A projekt az Európai Unió támogatásával, az Európai Szociális Alap társfinanszírozásával valósult meg.

\section{Szakirodalmi hivatkozások}

[1] Fadele Ayotunde Alaba, Mazliza Othman, Ibrahim A.T. Hahsem, Faiz Alotaibi: Internet of Things Security: A Survey. Journal of Network and Computer Applications, 2017, 88:10-28.

[2] Adafruit, (2017, May 14). https://www.adafruit.com/product/155

[3] Arduino, (2017, May 14). https://www.arduino.cc/en/main/arduinoBoardUno

[4] Sander van Vugt: Setting up a LAMP Server the Definitive Guide to SUSE Linux Enterprise Server 12, 309-329.

[5] Sanjib Sinha: Python Environment. Beginning Ethical Hacking with Python. 39-41.

[6] Murat Yener, Onur Dundar Android Application Development with Android Studio. Expert Android ${ }^{\circledR}$ Studio, 45-79.

[7] Autodesk Circuits, (2017, May 14). https://circuits.io/

[8] A. J. C. Trappey, Ch. Trappey, Usharani Hareesh Govindarajan, J. J. Sun: A review of essential standards and patent landscapes for the Internet of Things: A key enabler for Industry 4.0. Advanced Engineering Informatics, 2016. 